\title{
Monitoring of vegetation on oil-contaminated soils and remediation potential of indigenous plant species
}

Panchenko L.V., Muratova A.Yu., Turkovskaya O.V.

Institute of Biochemistry and Physiology of Plants and Microorganisms, Russian Academy of Sciences, Saratov, Russia E-mail: lvpanchenko56@yandex.ru

Key message. The remediation potential of the indigenous plant species growing on oil-contaminated soils is substantiated as basis for development approaches to natural phytoremediation.

Keywords: oil pollution, phytoremediation potential, rhizosphere, degradation genes

Studies of the revegetation and natural remediation of contaminated soil is still relevant. On the basis of the long-term field research we tried to reveal the regularities of vegetation cover development on oil-contaminated soils of the steppe zone of the Volga Uplands, and to identify plant species, which make the main contribution to the remediation process. Taxonomic and ecological-coenotic analyzes were carried out. The concentrations of petroleum hydrocarbons, available nitrogen, the number of total heterotrophic and the oil-oxidizing microorganisms in the rhizosphere of most common 79 plant species and in neighboring bulk soils were determined. This allowed us to characterize the phytoremediation potential of the native plant species studied.

In all rhizosphere samples, the content of petroleum hydrocarbons was 2-3 times lower than in soil without plants taken from the same site. According to the data obtained, the highest phytoremediation potential was determined for yellow medick (Medicago falcate L.), alfalfa (Medicago sativa L.) and hop medick (Medicago lupulina), barnyard grass (Echinochloa crusgalli), tatarian orache (Atriplex tatarica) and brown nonea (Nonea pulla).

Using molecular genetic approaches for characterization of rhizospheric communities showed that the rhizosphere of $M$. falcata and non-rhizospheric bulk soil reveald the highest relative abundance of the alkane degradation gene alkB in their microbiomes. The abundance of the aromatic degradation gene nah was also maximum in the rhizosphere of $M$. falcata, that was an order of magnitude higher than for other plants. The dominant position in all samples of the oil-contaminated soil studied was occupied by representatives of Actinobacteria and Proteobacteria. The rhizosphere communities of plant species were noticeably distinguished. In the rhizosphere of M. falcata, a significant part of Firmicutes phylum represented by Bacillus as the only genus was noted. The Gemmatimonadetes phylum was distinguished in the rhizosphere of E. crus-galli. The rhizosphere community of $M$. falcata had the smallest taxonomic diversity that may be due to the selective effect of the plant root exudates on the formation of its rhizomicrobiome.

\section{Мониторинг растительного покрова на нефтезагрязненных почвах и ремедиационный потенциал образующих его растений}

Панченко Л.В., Муратова А.Ю., Турковская О.В.

Институт биохимии и физиологии растений и микроорганизмов РАН, Саратов, Россия

\begin{abstract}
Аннотация. Обоснован ремедиационный потенциал аборигенной флоры нефтезагрязненных почв, который позволяет использовать ее и выявленные перспективные растительные виды для разработки приемов естественной фиторемедиации.

Ключевые слова: нефтяное загрязнение, фиторемедиационный потенщиал, ризосфера, гены деградации.

Исследования процессов восстановления растительного покрова и естественной ремедиации на загрязненных территориях остаются по-прежнему актуальными. На основе данных многолетних полевых исследований мы постарались осветить закономерности формирования растительного покрова на нефтезагрязненных почвах степной зоны Приволжской возвышенности и выявить растительные виды, которые вносят основной вклад в процесс ремедиации. Были проведены таксономический и эколого-ценотический анализы; определены концентрации нефтяных углеводородов, доступного азота, общей численности микроорганизмов и нефтеокисляющих микроорганизмов в ризосфере 79 наиболее часто встречающихся растительных видов и в почве без растительности, что позволило охарактеризовать фиторемедиационный потенциал этих растений.

Во всех ризосферных образцах содержание нефтепродуктов было в 2-3 раза ниже, чем в почве без растений, отобранной с того же участка. Согласно полученным данным наибольшим фиторемедиационным потенциалом обладали люцерны серповидная (Medicago falcata), посевная (Medicago sativa) и хмелевая (Medicago lupulina), ежовник обыкновенный (Echinochloa crus-galli), лебеда татарская (Atriplex tatarica) и нонея темно-бурая (Nonea pulla).

Использование молекулярно-генетических подходов для характеристики ризосферных сообществ показало, что ризосфера M. falcata и неризосферная почва демонстрировали наибольшую относительную обогащенность своих микробиомов геном деградации алканов alkB. Численность генов деградации ароматических соединений nah была максимальной также в ризосфере $M$. falcata, на порядок превышая этот показатель для других растений. Доминирующее положение во всех образцах исследуемой нефтезагрязненной почвы занимали представители фил Actinobacteria и Proteobacteria. На фоне общего рисунка таксономических профилей заметно выделялись ризосферные сообщества M. falcata и E. crus-galli. В ризосфере M. falcata отмечалась значительная доля Firmicutes, представленной единственным родом Bacillus, а в ризосфере E. crus-galli - доля Gemmatimonadetes. Ризосферное сообщество M. falcata характеризовалось наименьшим таксономическим разнообразием, что может быть связано с селективным действием корневых выделений растения на формирование своего ризомикробиома.
\end{abstract}

